\title{
HUBUNGAN EFIKASI DIRI DENGAN KEPATUHAN MINUM OBAT PADA PASIEN TBC DI WILAYAH KERJA PUSKESMAS PARONGPONG KECAMATAN PARONGPONG KABUPATEN BANDUNG BARAT
}

\author{
RELATIONSHIP OF SELF-EFICACY WITH MEDICATION \\ ADDHERANCE IN TB PATIENTS AT THE WORKING AREA OF PUBLIC \\ HEALTH CENTER, PARONGPONG, WEST BANDUNG
}

\author{
Mella Yusef Fintiya ${ }^{1}$, Imanuel Sri Mei Wulandari ${ }^{2}$ \\ Fakultas IImu Keperawatan, Universitas Advent Indonesia \\ E-mail: mellayuseff@gmail.com
}

\begin{abstract}
ABSTRAK
Pendahuluan: Tuberkulosis adalah penyakit infeksi paru yang disebabkan oleh Mycobacterium Tuberculosis. Di Indonesia kasus tuberkulosis setiap tahunnya semakin meningkat. Indonesia menepati urutan ke-6 penderita tuberkulosis tertinggi di dunia, sedangkan Jawa Barat menepati urutan pertama. Tujuan: Tujuan penelitian ini adalah untuk melihat adanya hubungan anatar efikasi diri dengan kepatuhan minum obat OAT. Metode: Metode penelitian menggunakan desain deskriptif korelasional dengan pendekatan cross sectional dengan melibatkan 23 responden yang sedang menjalani pengobatan di puskesmas parongpong, responden dipilih dengan menggunakan Purposive sampling. Variabel independen adalah efikasi diri, variabel dependent adalah kepatuhan minum obat. Instrumen dalam penelitian ini adalah kuesioner yang dianalisis menggunakan pearson's $r$. Hasil: Hasil dan analisis Efikasi Diri dengan Kepatuhan Minum obat mempunyai hubungan dengan nilai $p$-value 0,030 atau ( $p \leq 0,05)$ dengan tingkat hubungan sedang (0,454). Diskusi: Efikasi merupakan salah satu faktor yang mempengaruhi kepatuhan minum obat pasien tuberkulosis di wilayah kerja Puskesmas Parongpong. Saran untuk penelitian selanjutnya perlu mengetahui peran kader kesehatan dalam kepatuhan minum obat.
\end{abstract}

Kata Kunci : Efikasi Diri, Kepatuhan Minum Obat, Tuberkulosis

\begin{abstract}
Introduction: Tuberculosis is a pulmonary infectious disease caused by Mycobacterium Tuberculosis. In Indonesia tuberculosis case every year is increasing. Indonesia kept the 6th highest tuberculosis sufferer in the world, while West Java kept the first order. Purpose: The purpose of this research is to see the relationship of self-efficacy with the adherence of OAT medication. Method: The research method uses a correlational descriptive design with a cross sectional approach by involving 23 respondents undergoing treatment at a parongpong Puskesmas, the respondent chosen using the Purposive sampling. Independent variables are self-efficacies, variable dependent is the adherence to taking medication. The instrument in this study is a questionnaire analyzed using Pearson's R. Results: Results and analysis of self-efficacy by taking compliance the drug has a relationship with the value of $P$-value 0.030 or $(P \leq 0.05)$ with a moderate relationship level (0.454). Discussion: Efficacy is one of the factors that affects the adherence to the treatment of patients with tuberculosis in the working area of Parongpong Puskesmas. Suggestions for further research need to know the role of health cadres in the compliance with medication.
\end{abstract}

Keywords: Self-Efficacy, Drug-Taking Compliance, Tuberculosis
JURNAL

SKOLASTIK

KEPERAWATAN

Vol, 5, No. 2

Juli - Desember 2019

ISSN: $2443-0935$

E-ISSN 2443 - 16990 


\section{PENDAHULUAN}

Tuberkulosis (TB) adalah penyakit infeksius kronik dan berulang yang biasanya mengenai paru, penyakit ini disebabkan oleh Mycobacterium tuberculosis. Tuberkulosis dapat ditularkan oleh orang lain melalui droplet, droplet yang ditularkan melalui udara dihasilkan ketika orang terinfeksi batuk, bersin, dan bicara. Droplet berukuran kecil sekali yang dapat beredar di udara selama beberapa jam. Infeksi dapat terjadi ketika seseorang yang rentan akan udara yang mengandung droplet nuklei dan partikel terkontaminasi menghindari pertahanan normal saluran napas atas untuk mencapai alveoli (Setiyadi dan Adi, 2019).

Pada tahun 2016, 10,4 juta orang jatuh sakit dengan TB, dan 1,7 juta meninggal karena penyakit ini (termasuk 0,4 juta di antara orang dengan HIV). Lebih dari 95\% kematian akibat Tuberkulosis terjadi di negara berpenghasilan rendah dan menengah. Pada Global Report 2016, $87 \%$ kasus Tuberkulosis baru terjadi di 30 negara dengan beban TB tinggi. Tujuh negara menyumbang $64 \%$ kasus Tuberkulosis yaitu: India, Indonesia, China, Filipina, Pakistan, Nigeria, dan Afrika Selatan (WHO, 2018). Tuberkulosis di Indonesia menempati peringkat ke-6 sebagai penyakit tertinggi di Indonesia ( Kemenkes RI, 2015).

Menurut Gobal Tuberculosis Report diperkirakan insidens tuberculosis di Indonesia pada tahun 2015 sebesar 395 kasus/100.000 penduduk dan angka kematian sebesar 40/100.000 penduduk. Menurut perhitungan model prediction yang berdasarkan data hasil survei prevalensi
Tuberkulosis tahun 2013-2014, prevalensi Tuberkulosis tahun 2015 sebesar 643 per 100.000 penduduk dan prevalensi Tuberkulosis tahun 2016 sebesar 628 per 100.000 penduduk (WHO, 2016).

Pada tahun 2016 ditemukan jumlah kasus Tuberkulosis sebanyak 351.893 kasus, meningkat bila dibandingkan semua kasus Tuberkulosis yang ditemukan pada tahun 2015 yang sebesar 330.729 kasus. Jawa Barat, Jawa Timur dan Jawa tengah merupakan tiga provinsi dengan angka kejadia Tuberkulosis tertinggi, sebanding dengan jumalh pendudukan yang tinggi juga. Kasus Tuberkulosis di tiga provinsi tersebut sebesar 44\% dari jumlah seluruh kasus baru di Indonesia (Kemenkes RI, 2016).

Tuberkulosis di Jawa Barat pada tahun 2015 menempati peringkat tertinggi dengan kasus Tuberkulosis dengan keseluruhan kasus 65.275 orang yang mempunyai hasil BTA positif 31.834 orang. Hal yang sama pada kasus Tuberkulosis di Jawa Barat pada tahun 2016 juga menempati peringkat tertinggi di indonesia yaitu terdapat 70.715 orang penderita Tuberkulosis, yang sudah datang berobat ke Rumah Sakit dan Puskesmas dengan total kasus baru BTA positif 30.785 orang (Kemenkes RI, 2017).

Menurut Novitasari, 2017 pada klien TB paru selain faktor fisik, penting juga memperhatikan faktor psikologis antara lain pemahaman individu yang dapat mempengaruhi persepsi terhadap penyakit dan dalam menjalani masa pengobatan. Keyakinan individu terhadap pengobatan dalam mencapai 
kesembuhan dari penyakit tuberkulosis paru yang sangat diperlukan. Efikasi diri dapat diperoleh, diubah, ditingkatkan, atau diurunkan. Ketika menghadapi kesulitan atau masalah seseorang yang memiliki efikasi diri yang rendah akan memperlambat pengobatannya dan melonggarkan upayanya atau aktivitasnya bahkan bisa sampai menyerah dalam pengobatan.

Menurut penelitian yang dilakukan Lusiatun, Mudigdo \& Murti (2016), didapatkan hasil kepatuhan berobat akan memberikan pengaruh terhadap status kesehatan pasien. Pasien yang rutin dalam pengobatan akan memiliki status kesehatan yang lebih baik dibandingkan dengan pasien yang tidak rutin dalam pengobatan. Kurangnya ketaatan dalam minum obat pada penderita tuberkulosis merupakan suatu permasalahan yang menghambat penyembuhan penyakitnya. Terdapat beberapa faktor yang dapat memberikan pengaruh terhadap kepatuhan berobat, yaitu adanya faktor dukungan sosial keluarga yang berasal dari pasangan hidup dan faktor efikasi diri.

Menurut Kemenkes, 2016, pengobatan TB untuk menyembuhkan pasien, mencegah kematian, mencegah kekambuhan, memutuskan rantai penularan dan mencegah terjadinya resistensi kuman terhadap obat anti tuberkulosis (OAT). Faktor utama penyebab terjadinya resistensi kuman terhadap (OAT) adalah seseorang yang dalam pengobatannya tidak dilaksanakan dengan teratur dan menghentikan pengobatan sebelum waktunya. Klien dinyatakan sembuh apabila klien dapat menyelesaikan pengobatan secara lengkap dan teratur dan melakukan pemeriksaan ulang dahak dengan hasil negatif pengobatan dan pada suatu pemeriksaan sebelumnya.

Penerimaan yang negatif ketika mengetahui dirinya menderita penyakit TB paru, menyebabkan kondisi emosional individu tersebut akan negatif seperti marah, cemas, Khawatir, takut, dan bahkan hingga mengalami krisis efikasi diri. Kekhawatiran yang berlebihan ketika penderita mengalami efek samping obat akan mempengaruhi suasana hati individu tersebut sehingga berdampak dalam prilaku minum obat selanjutnya. Efikasi diri dapat memberikan pengaruh pada persepsi pasien tuberkulosis paru tentang efikasi diri untuk membentuk perilaku positif pada masa pengobatan.Tujuan dari penelitian ini adalah untuk mengetahui tingkat efikasi diri penderita Tuberkulosis, tingkat kepatuhan, serta Hubungan antara Efikasi Diri dengan Kepatuhan Minum Obat Pasien TBC di Wilayah Kerja Puskesmas Parongpong Kabupaten Bandung Barat.

\section{METODOLOGI PENELITIAN}

Penelitian ini menggunakan desain penelitian deskriptif korelasional dengan pendekatan cross sectional. Sampel adalah klien dengan TB Paru yang sedang menjalani pengobatan OAT. Teknik sampling yang digunakan dalam penelitian ini adalah Purposive sampling, jumlah responden dalam penelitian ini adalah 23 klien dengan TB. Variabel independent dalam penelitian ini adalah efikasi diri. Variabel dependent dalam penelitian ini adalah kepatuhan minum obat. Instrumen 
dalam penelitian ini adalah kuesioner tenatng efikasi diri dan kepatuhan minum obat TB.

Dalam kuesioner efikasi diri terkait dengan pertanyaan tentang keyakinan diri pasien dalam menjalankan pengobatan OAT yang meliputi keyakinan mendapatkan informasi, keyakinan mendapatkan dukungan sosial serta mengatasi gangguan fisik dan emosi, sehingga pernyataan untuk mengukur tingkat keyakinan klien TB paru berisi 20 item pertanyaan dengan pilihan jawaban sangat yakin (5), yakin (4), cukup yakin (3), tidak yakin (2) dan sangat tidak yakin (1)

Kuesioner kepatuhan minum obat OAT, yang terdiri dari 8 pertanyaan dengan menggunakana skala guttman. Dengan jawabana ya (0) dan tidak (1).

Penelitian ini dilakukan di Wilayah Kerja Puskesmas Parongpong Kecamatan Parongpong Kabupaten Bandung Barat. Data efikasi diri diukur menggunakan uji statistik pearson's $r$ yaitu jika ditetapkan nilai $\alpha=0,05$ dan diperoleh nilai signifikansi $\leq 0.05$ maka H1 maka diterima yaitu ada hubungan antar efikasi diri dengan kepatuhan minum obat pada pasien TB paru.

\section{HASIL DAN PEMBAHASAN}

\section{Karakteristik responden penderita Tuberculosis}

Di bawah ini akan dijabarkan data demografi responden mengenai karakteristik demografi 23 responden pada penelitian ini. Tabel Karakteristik responden penderita Tuberculosis di Wilayah Kerja
Puskesmas Parongpong Kecamatan Parongpong Kabupaten Bandung Barat, 28 Oktober - 10 November 2019.

Tabel 1. Karakterisitik Responden

\begin{tabular}{|c|c|c|c|}
\hline No & Karakteristik & $\begin{array}{l}\text { Frekuen } \\
\text { si }(f)\end{array}$ & $\begin{array}{l}\text { Present } \\
\text { ase }(\%)\end{array}$ \\
\hline \multirow[t]{8}{*}{1} & Usia & & \\
\hline & Remaja Akhir & 4 & 17.4 \\
\hline & Dewasa Awal & 4 & 17.4 \\
\hline & Dewasa Akhir & 9 & 39.1 \\
\hline & Lansia Awal & 3 & 13.0 \\
\hline & Lansia Akhir & 2 & 8.7 \\
\hline & Manula & 1 & 4.3 \\
\hline & Total & 23 & 100.0 \\
\hline \multirow[t]{4}{*}{2} & Jenis Kelamin & & \\
\hline & Laki-laki & 9 & 39.0 \\
\hline & Peremuan & 14 & 60.9 \\
\hline & Total & 23 & 100.0 \\
\hline \multirow[t]{6}{*}{3} & Pekerjaan & & \\
\hline & Pegawai Swasta & 4 & 17.4 \\
\hline & Pedagang & 4 & 17.4 \\
\hline & Pelajar/Mahasiswa & 1 & 4.3 \\
\hline & Tidak Berkerja & 8 & 34.8 \\
\hline & Lainnya & 6 & 26.1 \\
\hline \multirow[t]{7}{*}{4} & Penghasilan & & \\
\hline & $<1.000 .000$ & 15 & 65.2 \\
\hline & $1.000 .000-1.500 .000$ & 3 & 13.0 \\
\hline & $1.500 .000-2.000 .000$ & 3 & 13.0 \\
\hline & $2.000 .000-2.500 .000$ & 1 & 4.3 \\
\hline & $3.000 .000-4.000 .000$ & 1 & 4.3 \\
\hline & Total & 23 & 100.0 \\
\hline \multirow[t]{7}{*}{5.} & Pendidikan & & \\
\hline & Terakhir & 12 & 52.2 \\
\hline & SD & 5 & 21.7 \\
\hline & SMP & 4 & 17.4 \\
\hline & SMA & 1 & 4.3 \\
\hline & Dipolma & 1 & 4.3 \\
\hline & $\begin{array}{l}\text { Sarjana } \\
\text { Total }\end{array}$ & 23 & 100.0 \\
\hline \multirow[t]{5}{*}{6.} & Status Perkawinan & & \\
\hline & Menikah & 17 & 73.9 \\
\hline & Duda & 1 & 4.3 \\
\hline & Belum Kawin & 5 & 21.7 \\
\hline & Total & 23 & 100.0 \\
\hline
\end{tabular}

Berdasarkan tabel di atas mengenai karakteristik responden menunjukan semua responden penderita tuberkulosis yang berobat di Wilayah Kerja Puskesmas Parongpong Kecamatan Parongpong Kabupaten Bandung Barat. Mayoritas penderita tuberkulosis 9 orang (39.1\%) dengan usia dewasa akhir, penderita tuberkulosis 4 orang (17.4\%) dengan 
usia remaja akhir, penderita 4 orang (17.4\%) dengan usia dewasa akhir, penderita 3 orang $(13.0 \%)$ dengan usia lansia awal, penderita 2 orang $(8.7 \%)$ dengan usia lansia akhir dan penderita 1 orang (4.3\%) dengan usia manula.

Sebanyak 14 orang (60.9\%) penderita tuberkulosis berjenis kelamin perempuan, sedangkan 9 orang (39.0\%) lainnya berjenis kelamin laki-laki.

Pekerjaan penderita tuberkulosis 8 orang $(34.8 \%)$ tidak berkerja, penderita 6 orang $(26.1 \%)$ lainnya, penderita 4 orang $(17.4 \%)$ pegawai swasta, 4 orang $(17.4 \%)$ pedagang, dan 1 orang (4.3\%) pelajar/mahasiswa.

Mayoritas penghasilan penderita tuberkulosis memiliki penghasilan satu juta setiap bulan nya. Penderita tuberkulosis didominasi menyelesaikan pendidikan terakhirnya adalah Sekolah Dasar. Status perkawinan penderita tuberkulosis mayoritas sudah menikah, 5 orang belum menikah dan 1 orang duda.

\section{Gambaran Efikasi Diri Penderita TBC}

Dari tabel di bawah dapat dilihat nilai rata-rata efikasi diri dari responden adalah 4,34 dengan St,. Deviasi 0,45. Nilai ini menunjukan bahwa nilai efikasi diri responden tinggi.

Efikasi diri diartikan sebagai pikiran seseorang kepada kemampuan dirinya untuk melaksanakan dan mengatur tindakan supaya dapat menyelesaikan suatu masalah atau mencapai tujuan tertentu (Fauzi, 2019).

Tabel 2. Gambaran Efikasi Diri

\begin{tabular}{l|c|c}
\hline Efikasi & Mean & St. Deviasi \\
\cline { 2 - 3 } Diri & 4,34 & $\pm 0,46$ \\
\hline
\end{tabular}

Menurut Sapiq, 2015 dalam Novitasari, 2017 efikasi diri sangat dibutuhkan seseorang untuk termotivasi, sadar dan mau melakukan kegiatan yang di anggap penting bagi dirinya.

Menurut Dwidiyanti, 2017 dalam Fauzi, 2019 menyatakan bahwa seseorang yang memiliki efikasi diri tinggi maka akan mempunyai keyakinan untuk sembuh. Pasien TB paru dengan tingkat efikasi tinggi akan mempunyai kesadaran untuk rutin minum obat dan mampu mempertahankan dalam kehidupan sehari-hari.

Hal tersebut sesuai dengan penelitian Sunda, Asyanti, \& Psi, (2019), bahwa ketaatan pada pengobatan tergantung pada kepercayaan atau keyakinan diri dari pasien dan persepsi pasien. Dengan demikian, orang yang sakit atau pasien dengan efikasi diri yang tinggi dapat melakukan suatu usaha guna bisa meningkatkan fungsi dari fisik, emosi, peran, kognitif dan sosialnya. Pasien tersebut akan berfikir secara optimis terhadap penyakit yang dimilikinya dan selalu berusaha untuk mengendalikan diri guna tetap kuat dalam menghadapi masalah yang dimiliki (Lusiatun, Mudigdo \& Murti, 2016).

\section{Gambaran Kepatuhan Minum Obat}

Dari tabel 3 dapat dilihat bahwa rata rata kepatuhan responden 85,87 
dengan St. Deviasi 17,3, hal ini menunjukan bahwa tingkat kepatuhan pasien dalam rentan tinggi. Menurut Islami, 2019, pasien yang berobat cenderung patuh untuk berobat ada lima kondisi, yaitu yang pertama, penderita mempunyai tingkat pengetahuan dan motivasi pada penyakit tuberkulosis yang dideritanya. Kedua, penderita harus diyakinkan bahwa penyakit Tuberkulosis suatu permasalahan kesehatan dan penyakit yang serius.

Tabel 3. Gambaran Kaptuhan Minum Obat

\begin{tabular}{l|c|c}
\hline Kepatuhan & Mean & St. Deviasi \\
\cline { 2 - 3 } $\begin{array}{l}\text { Minum } \\
\text { Obat }\end{array}$ & 85,87 & 17,3 \\
\hline
\end{tabular}

Ketiga, penderita harus diyakinkan untuk patuh kepada pengobatan yang efektif agar menyembuhkan penyakitnya. Keempat, memotivasi melalui rangsangan internal dan eksternal agar untuk memicu prilaku kesehatan penderita seperti minum obat. Ke lima, memotivasi keyakinan self-efficacy penderita secara ketat untuk mengikuti pengobatan hingga sampai periode perawatan akhir.

\section{Hubungan Efikasi dengan Kepatuhan minum obat.}

Tabel 4. Hubungan Efikasi dengan Kepatuhan Minum Obat.

\begin{tabular}{|l|l|c|c|}
\hline & $\begin{array}{l}\text { Mea } \\
\mathrm{n}\end{array}$ & $\begin{array}{c}\text { Signifik } \\
\text { an }\end{array}$ & $\begin{array}{c}\text { Tingkat } \\
\text { Hubung } \\
\text { an }\end{array}$ \\
\hline $\begin{array}{l}\text { Efikasi } \\
\text { diri }\end{array}$ & 4,34 & 0,030 & 0,454 \\
\cline { 1 - 1 } $\begin{array}{l}\text { Kepatuh } \\
\text { an } \\
\text { minum } \\
\text { obat }\end{array}$ & 4,23 & & \\
\hline
\end{tabular}

Dari tabel di atas dapat dilihat bahwa $p$ value 0,030 . Hal ini menunjukan $p$ value < 0,05 . Dengan kata lain efikasi diri mempunyai hubungan yang positif dengan kepatuhan minum obat dengan nilai korelasi 0,454 (hubungan sedang).

Dalam penelitian Sutrisna (2017), menunjukan bahwa efikasi diri mempengaruhi kepatuhan pengobatan TB paru. Pengalaman sebelumnya dalam mencapai suatu keberhasilan atau prestasi adalah pembentuk efikasi diri yang paling akuat, pengalaman dalam menyelesaikan pengobatan saat fase intensif dapat membentuk efikasi diri menyelesaikan pengobatan fase lanjutan. Berbagai pengalaman lain yang berhubungan akan mempengaruhi prilaku selanjutnya. Klien TB paru cenderung mengamati prilaku penderita TB paru lain dalam menjalani pengobatan. Kegagalan atau keberhasilan dalam pengobatan dapat mempengaruhi tingkat efikasi diri penderita.

Menurut Sapiq (2015) menyatakan semakin tinggi efikasi diri yang dimiliki seseorang yang menderita TB paru maka akan semakin patuh akan pengobatan OAT.

\section{KESIMPULAN}

1. Responden dalam penelitian ini memliki tingkat efikasi diri yang tinggi dengan nilai rata-rata 4,34.

2. Kepatuhan Minum obat responden masuk dalam kategori tinggi, menunjukkan bahwa responden dalam penelitian ini patuh mengikuti program pengobatan Tuberkulosis.

3. Terdapat Hubungan antara Efikasi diri dengan Kepatuhan minum obat dengan nilai korelasi 0,030 dimana $p$ 
value lebih kecil dari nilai alfa. Dengan keeratan hubungan sedang 0,454 .

\section{SARAN}

Kepada anggota masyarat untuk mempertahankan kepatuhan minum obat setiap diberikan dengan arahan dokter. Bagi tim kesehatan untuk meningkatkan asuhan edukasi yang mendukung kepatuhan minum obat, sehingga program pengobatan pada pasien dengan Tuberkulosis dapat terlaksana dengan berhasil dan menurunkan angka kejadian Tuberkulosis di wilayah kerja Puskesmas Parongpong.

\section{DAFTAR PUSTAKA}

Budi, I. S., Ardillah, Y., Sari, I. P., \& Septiawati, D. (2018). Analisis Faktor Risiko Kejadian Penyakit Tuberculosis Bagi Masyarakat Daerah Kumuh Kota Palembang. Jurnal Kesehatan Lingkungan Indonesia, 17(2), 87-94.

Fauzi, Y. S. (2019). Hubungan Antara Efikasi Diri Terhadap Kepatuhan Minum Obat Anti Tuberkulosis (Oat) Di Puskesmas Rawat Inap Panjang.

Islami, N. S. (2019). Analisis Faktor Yang Berhubungan Dengan Self Efficacy Klien Tb Paru Dalam Menjalani Pengobatan Di Puskesmas Wilayah Kota Surabaya (Doctoral Dissertation, Universitas Airlangga).

Isnani, N. (2019). Karakteristik Pasien Yang Mendapat Terapi Anti Tuberkulosis Pada Penderita Tuberkulosis Pasien Rawat Jalan Di Puskesmas Pekauman Kota
Banjarmasin. Jurnal Kajian Ilmiah Kesehatan Dan Teknologi, 1(2), 15-20.

Kementerian Kesehatan Republik Indonesia. (2016). Peraturan Menteri Kesehatan Republik Indonesia No. 67 Tentang Pedoman Penanggulangan Tuberkulosis. Jakarta: Kementerian Kesehatan RI.

Kementerian Kesehatan Republik Indonesia. (2017). Data Dan Informasi Profil Kesehatan Indonesia 2016. Jakarta: Pusat Data Dan Informasi Kementrian Kesehatan RI.

Lusiatun, L., Mudigdo, A., \& Murti, B. (2016). The Effect Of SelfEfficacy, Family Support, And Socio-Economic Factors On The Quality Of Life Of Patients With Breast Cancer At Dr Moewardi Hospital. Journal of Epidemiology And Public Health, 1(3), 182-194.

Novitasari, R. (2017). Hubungan Efikasi Diri Dengan Kepatuhan Minum Obat Pada Pasien TB Paru Di Puskesmas Patrang Kabupaten Jember.

Pujiastuti, S. R., Safitri, W., \& Adi, G. S. Gambaran Pengetahuan Pasien Tentang Penyakit Tuberkulosis (TBC) Di Wilayah Kerja Puskesmas Andong Boyolali.

Sapiq, A, 2015. Hubungan Self Efficacy Dan Konsep Diri Dengan Kepatuhan Minum Obat Pada Penderita TB Paru Di Wilayah Kerja Pekauman Banjarmasin Selatan Tahun 2015. 
Setiyadi, D., \& Adi, M. S. (2019).

Pengetahuan, Praktik Pencegahan

Dan Kondisi Rumah Pada Kontak

Serumah Dengan Penderita Tb

Paru Di Kabupaten Demak.

Visikes: Jurnal Kesehatan

Masyarakat, 18(1).

Sugiarto, S., Herdianti, H., \&

Entianopa, E. (2018).

Pengetahuan, Persepsi, Self

Efficacy Dan Pengaruh

Interpersonal Penderita Terhadap

Pencegahan Penularan TB Paru

(Descriptif Study). Gorontalo Journal Of Public Health, 1(2), 5664.

Sunda, E., Asyanti, S., \& Psi, S. (2019). Hubungan Dukungan Keluarga Dan Efikasi Diri Dengan Kepatuhan Pengobatan Pada Pasien Tuberculosis Di Wilayah Kerja Puskesmas Bandarharjo Semarang (Doctoral Dissertation, Universitas Muhammadiyah Surakarta).

Sutrisna, A. A. (2017). Hubungan Efikasi Diri Dengan Kepatuhan Minum Obat Penderita Tuberkulosis Paru Di Rumah Sakit Paru Respira Yogyakarta (Doctoral Dissertation, STIKES Jenderal Achmad Yani Yogyakarta).

Yulianti, Y. (2018). Hubungan Efikasi Diri Dan Dukungan Keluarga Dengan Kepatuhan Minum Obat Pada Penderita Tuberkulosis Di Wilayah Kerja Puskesmas Sukabumi Kota Sukabumi. Jurnal UMMI, 12 (3), $5-60$ 